\title{
EXCURSION TO GROVE PARK AND CHISLEHURST.
}

\author{
SatUrday, March 2OTH, I920. \\ Report by L. Dudley Stamp, M.Sc., F.G.S. \\ Director of the Excursion.
}

A PARTY of about 50 assembled at Grove Park Station at 2.20 p.m., and walked in a southerly direction towards Sundridge Park. On a spur of high ground overlooking the Golf Links, a short halt was made and some features of the local geology explained. The party was here standing on London Clay, and looking eastwards, the high ground occupied by Elmstead Wood (also consisting of London Clay) was seen. The intervening valley, in which the little River Quaggy flows, is cut in Oldhaven Sands and Woolwich Beds. The Director remarked that the Eocene beds of South-east London were by no means horizontal There are two sets of broad gentle folds, approximately at right angles*; the one set running North-east to South-west, the other north-west to South-east. An example of the first set is seen in the syncline running from Shooter's Hill to Crystal Palace (London Clay). Shooter's Hill was hidden in the haze, but the high ground of Eltham to the South (formed by Blackheath Beds on the south-eastern limb of the syncline) was seen. An anticlinal member of the second series was chiefly responsible for the Chalk inlier of EImstead (seen later in the afternoon), and for the North-western prolongation of the Chalk inlier at New Cross. These two, the Shooter's Hill Syncline and the Elmstead-New Cross Anticline practically neutralise each other between Hither Green and Grove Park, and near where the party was standing. Owing also to the existence of these two sets of folds the Elmstead inlier partakes of the nature of an elongated dome rather than that of a simple anticline.

Turning to the left the party followed the lane towards Motingham across the Golf Links and reached the railway cutting near the north-western end of Elmstead Tunnel. Here the pebbly Basement-Bed of the London Clay, resting on about Io feet of clean Oldhaven Sand, $\dagger$ could be made out although the sides of the cutting were well grassed. Rabbits cause considerable damage by burrowing in the soft sand just below the clayey Basement-Bed. The bottom of the cutting touches Woolwich Shell Beds, which here consist of a brownish clay, full of fluviatile shells--Paludina and Unio-together with estuarine Cyrene in the lower part. The Director passed round a specimen, which had been obtained in a small excavation

"C. E. N. Bromehead, Sum. Prog. Geol. Surv. for I913 (19r4), p. 28.

†W. Whitaker, Geology of London, vol. I, p. 226, M em. Geot. Surv. (t889). 
near the Signal Box, showing all three forms. It was remarked that the Paludina Bed is not of the usual calcareous type, but distinctly a clay bed. After noting some shallow trench sections cut in Oldhaven Sand with a few pebbles (near the western corner of the Golf Links) the party proceeded over the hill, following the line of Elmstead Tunnel. The surface of the ground was somewhat confused by Blackheath material from tunnel trial holes. From the hill-top the valley occupied by the Chalk inlier was seen, with high ground of Blackheath Beds on either side, sloping gently away from the axis of the fold. Descending the hill the next halt was made at the famous Sundiidge Rock Pit, situated Ioo yards north-east of Elmstead Station. Sir Cyril and Lady Harrison, in whose garden the pit is situated, were waiting to receive the Association.

The pit is in pebbly Oldhaven Sands, which are here upwards of 40 fect in thickness and rest on a highly eroded surface of Woolwich Beds. In the railway cutting, close by, they were formerly seen to repose on about 2 or 3 feet of the Bottom Bed of the Woolwich Series.* The false dip of the Blackheath Beds is between Io and 25 degrees to the north, being highest in the upper part. $\dagger$ The upper part consists of banks of oysters (Osirea bellovacensis) cemented into hard rock by calcareous cement (hence the name--Sundridge Rock Pit). The beds are fossiliferous throughout, but the fossils in the loose sands are extremely fragile. The Director remarked on the very definite and distinct nature of the Blackheath fauna, consisting, as it does, of a mixture of estuarine and marine species. The occurrence of a few estuarine or fluviatile shells in a marine deposit is of comparative little importance as they may have been brought in by rivers emptying into the sea ; but the occurrence of marine shells mixed with estuarine in a deposit succeeding one with estuarine species only, indicates a marked change of conditions. The Woolwich Shell Beds have essentially a brackish water fauna or in some localities (as at Elmstead) a freshwater one. The succeeding Blackheath Beds have a number of the Woolwich estuarine species together with a considerable proportion of marine species. Although it has been suggested that they were formed as shingle banks holding back freshwater lagoons, in which the Woolwich Paludina Beds were deposited, i.e., contemporaneously, the character of the beds is entirely inconsistent with this idea. The perfect rounding of the pebbles and the absence of bleaching, point to a distinctly submarine, rather than coastal, origin.\$ Moreover, the Blackheath Beds always rest on an

*Ibid. p. 227.

tIbid. p. 227.

4C. E. N. Bromehead, Q.J.G.S., vol. ixxv (1919), p. ३о.

¿W. Whitaker, Q.J.G.S., vol. xxii (1866), p. 415. Geol. London IBasin, Mcm. Gool. Swrv., vol iv (1872), p. 240. Geol. of London, vol. i (1889), p. 215 , Mem. Geol. Surv. 
eroded surface of the underlying Woolwich Beds and even include rolled fragments of them.* Whilst the assemblage of heavy minerals of the former is identical with that of the underlying beds; the percentage (in patches) is very high, as if the sand had been naturally "panned" by current action. $\dagger$ A sample of sand from this pit gave . $208 \%$; another of Blackheath sand from Eltham Park Railway-cutting gave .325\%; whilst a sample of Thanct Sand from the Willett's pit (visited later in the afternoon), only gave $.095 \%$ and that is considerably above the average for Thanet or Woolwich Beds. The usually "clean" nature of the Blackheath Sands also seems to indicate natural washing of the sand by currents. The fossils found in this pit during the excursion included the following brackishwater species:-Cyrena (Corbicula) cuneiformis Fer., Cyrena spp., Melania inquinata Defr., Potamides funatus (Mant) and. Ostrea bellovacensis Lamk. : and the following marine species, Pectunculus (Axinea) plumsteadiensis Sow., Calyptraa trochiformis Lamk., Serpula, ? Arca and several examples of Polyzoa (?Flistra) encrusting Ostrea. Small freshwater species (probably floated into the Blackheath Sca) also occur, and several examples of the tiny Planorbis hemistoma Sow. were found together with small (probably young) Cyrence, inside the valves of larger Cyrenae by Mr. A. Wrigley. Before leaving the pit the President proposed a hearty vote of thanks to Sir Cyril Harrison, who had not only given the Association permission to visit the exposure but harl also taken a great deal of trouble in having the pit cleared of all obstacles, so that a truly magnificent section was seen by the visitors. Sir Cyril, replying, expressed a cordial welcome to geologists.

The party then proceeded towards Chislehurst, halting at the disused Chalk-pit at the back of Messrs. W. Willett's premises in Iower Camden (by kind permission of Messrs. Willett). The upper part of the section is in Thanet Sand, with the Bullhead Bed at the base and resting somewhat irregularly on the Chalk. The lower three or four feet of the Thanet Sand is very glauconitic and for six or eight feet from the base is unusually coherent. It is not unlike some of the softer varieties of "tuffeau" occurring in North France at about this horizon. It is a likely rock in which to search for fossils, indeed, some nicely preserved casts of worm burrows had been found, but, unfortunately, the section is very inaccessible. The coherence of the rock is not due to calcareous matter, but a large amount of argillaceous material (about 25\%) was found to be present. It is of interest to note that it was probably from this pit that Miss M. I. Gardiner obtained a sample of sand studied in her pioneer work on the mineralogical constitution of sands. $+\mathrm{A}$

-H. A. Baker, Geol. Mag., I920; p. 62.

+Cf. P. G. H. Boswrll, Q.J.G.S., vol. Ixxi (1015), p. 566 .

" The Greensand Bed at the Base of the Thartet Sand." Q.J.G.S., vol. xliv (r 888 ), p. 755. 
curious feature of the Chalk in this locality is the presence of certain indurated layers, one of which, about 18 inches thick, has been utilised to form the roof of artificial "caves" in this and in neighbouring quarries.

After tea at the Bickley Hotel, the President moved a hearty vote of thanks to the Director. Some of the members, taking advantage of the remaining daylight of a remarkable spring day, walked up on to Chislehurst Common and saw part of the extensive plateau, sloping gently with the dip of the beds, to the north. The Common is formed by Blackheath Pebble Beds, and is still largely covered with silver birch, a tree that thrives particularly well on these beds. It was seen that Chislehurst well deserves its name (A.S. cisil, O. H. Germ, chisil, gravel ; A. S. Hyrst, M. H. Germ, hurst, a wood.)

Mr. E. E. S. Brown acted as Excursion Secretary.

\section{REFERENCES.}

Maps.-Geological Survey, Iin., London District, Sheet 4. Ordnance Survey, rin., Large Sheet Series, Sheet I I6.

Previous Excursions.-

I897. W. Whitaker and T. V. Holmes, Proc. Geoi. Assoc., vol. xv., p. 108. 1900. T. V. Holmes. Proc. Geol. Assoc., vol. xvi., p. 522.

I9oI. T. V. Holmes., Proc. Geol. Assoc., vol, xvii., p. I36.

1902. T, V. Holmes and C. W. Osman, Proc. Geol. Assoc., vol. xvii., pp. 368 and 489 . 